\title{
Male Voices in Female Bodies: The Case of Chenjerai Hove's Androcentrism
}

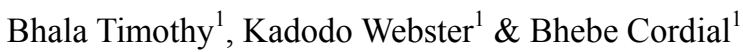 \\ ${ }^{1}$ Great Zimbabwe University, Department of Curriculum Studies, Masvingo, Zimbabwe, Africa \\ Correspondence: Kadodo Webster (Mr), Great Zimbabwe University, Department of Curriculum Studies, \\ Masvingo, Zimbabwe, Africa. Tel: 263-077-629-4721. E-mail: kadodoweb@yahoo.com
}

Received: October 1, 2012 Accepted: November 17, 2012 Online Published: January 17, 2013

doi:10.5539/ells.v3n1p47 URL: http://dx.doi.org/10.5539/ells.v3n1p47

\begin{abstract}
The article is an analysis of Chenjerai Hove's three novels in English namely Bones (1988), Shadows (1991) and Ancestors (1996). It argues that while Hove, to some extent, attempts to visibilize women in a predominantly male dominated society, he does not do much to suggest that women have the capacity to fully liberate themselves from patriarchal dominance. Hove is more of a pacifier who is not convincing in his quest for the emancipation of the African woman. This conclusion comes from a close analysis of Hove's depiction of female characters in the three novels mentioned above.
\end{abstract}

Keywords: androcentrism, phallocentrism, patriarchy, trope

\section{Introduction}

The contention that women suffer all forms of oppression in male dominated societies like Zimbabwe is an issue beyond debate. What could be contestable is the extent of this oppression, its nature and how best it should be addressed. Campaigns to emancipate women from traditionally unjust practices, beliefs or values have been a part of Zimbabwean experience since independence in 1980. These have come in different forms and not least through the literary discourse. Chengerai Hove, among the top post independence writers of Zimbabwean literature, is widely known for being the first male writer to prioritize gender role negotiation in his writings with the view to changing widely held perceptions about women. It is the submission of this paper that while there is abundant evidence from Hove's novels, namely Bones (1988), Shadows (1991) and Ancestors (1996), that he acknowledges the existence of unfair sexual relations, and to some extent, the need for attitudes to be changed. He, nonetheless, appears decidedly pessimistic as epitomized by his protagonists (all females) who neither have the strength, character nor level of conscious sophistication (high) enough to suggest that they can meaningfully alter their living conditions. While Hove's protagonists are clearly victims of a phallocentric order who negotiate their identities against a backdrop of limitations imposed by this order, they never really rise above a rudimentary understanding of their political milieu (Zhuwarara, 1996 in Ngara, 1996. Hove's gender role negotiation is male-centred, serving more to confirm widely held perceptions about women rather than change them.

\section{Theoretical Framework}

Feminism is employed as an analytic prism to explore, not just Hove's depiction of women, but also the totality of conditions that shape their behaviour. Feminism, among other concerns, revolves around the recognition of existing women's oppression and addresses the prevailing unjust and discriminatory gender relations (Mannathoko, 1992; Mtarangwi, 2000; Hellum, Stewart, Sardar Ali and Tsanga, 2007). Women, especially in Africa, continue to be marginalized in virtually all spheres of life, hence there is a need to explore ways that can help to bring meaningful justice and equality in the manner society perceives them. Eagleton (1995: 2) describes feminist critical paradigm as "a broad church with a number of co-operating approaches". Thus, it is an analytic tool to be used here since it allows for a pluralistic analysis of texts from its different critical positions. It benefits from many other theoretical underpinnings that include Freud's psychoanalysis, French structuralism of Derrida and Lacan, Althuser's politics and ideology as well as Marx and Engels' Marxist criticism.

By employing feminist literary criticism, the article is able to delve deep into the whole gamut of forces that have shaped the female psyche to date which include the historical, political, economical and ideological. 
Writers, as social critics, present what they perceive as happening in society by observing and interpreting the norms, values and customs of society hence they become important barometers of societal attitudes or beliefs (Ngcobo, 1988). Through his or her personal convictions, the writer may affirm or destroy these social values and attitudes. It is with these ideas in mind that the analysis tackles Hove's texts with a view to establishing in what ways his depiction of women could help shape positive attitudes towards them. The need to change our societal perceptions of women, and as a result our social order for the better, is an issue beyond debate, hence studies such as this one could help provide valuable information towards that end. What Hove has done in conceptualizing and presenting the problems associated with women's struggles in the Zimbabwean experience, how he has depicted their sensibilities and choices are crucial concerns of this article.

\section{Hove: A Brief Literary History}

Hove belongs to that group of authors that rose to prominence in the post independence era commonly referred to as the 'second generation writers' (Veit Wild, 1993; Engelke, 1998). These writers are notable for their open mindedness and criticism of the society and politics of post independence Zimbabwe. Hove appears to have been profoundly influenced by the effects of the war of liberation on the rural poor that feature prominently in his novels. To date, he has published several major works of art, a number of which are not part of this analysis. To begin with, Hove carved his niche in the Zimbabwean literary sphere as a poetic observer of the armed struggle with his collection entitled Up In Arms (1982). This collection set out to portray the sufferings, experiences and heroic deeds of the common people during Zimbawe's war of liberation (Ngara, 1990). Up In Arms was followed by another collection entitled Red Hills of Home (1985). Hove's debut novel in English came in 1989 with the publication of Bones. This was followed by a novella entitled Shadows (1991) that in most respects show some intertextuality with his third novel Ancestors (1996). Ancestors, was followed by a collection of essays covering a range of issues entitled Palaver Finish (2002). Apart from this, Hove has published other works in Shona. Zhuwarara (1996) posits that Hove's Bones has the distinction of being one of the first novels in Zimbabwean literature to focus on African reactions to colonialism from the point of view of gender. In Shadows and Ancestors, Hove continues to use women's lived experiences as an organizing principle to tackle male-female relationships in Zimbabwean society. It is not surprising therefore, that in all these three selected novels the protagonists and centre of interest are women.

\section{Empowering the Voiceless? - Bones}

As a writer, Hove sees his responsibility as that of

Teacher and conscience of his people whose duty is to give voice to the

voiceless, the powerless, the victims of both power and circumstances..

..The ultimate goal being to create a world of human dignity and love

(Veit Wild, 1993: 314).

And true to his commitment 'to give voice to the voiceless', Hove has placed the poor illiterate farm labourer Marita at the center of his story in Bones. For this article, therefore, Hove's depiction of Marita in all her different roles as a wife, a labourer, a woman and a mother shall be the focal point. Marita's experiences in their totality symbolise those human aspirations that point to the need for freedom and self-fulfillment (Zhuwarara, 1996). She strives for recognition as a human being who deserves respect and she seeks to carve out a dignified existence in a predominantly patriarchal world. In Bones, and indeed in both Shadows and Ancestors, Hove creates a world in which women are victims of male created oppressive circumstances whose net effect is to silence them. It is against these oppressive circumstances politically or socially that Marita rebels. We get all this through the voice of Janifa, another central female character, through whose memory Marita is given form and character. While there are few other male characters such as Chisaga and Marume who take up Marita's story, the bulk of the narrative in Bones is centred on Marita herself, Janifa and the unnamed female traveler who shares the seat with Marita on her fateful journey to town. It is mainly through these female voices that Hove seeks to negotiate spaces for marginalized citizens. This allocation of narrative power shows the significance he places on the female perspective, which is commendable. Meyer (1998: 170) posits that

Hove sets up a new fictional mode intent on speaking with the voice

of those who are not literate but who are rich in courage and were

at the centre of the war as disposed peasants.

In other words, by encoding the lived experiences of these women, Hove is inscribing and acknowledging the female experience in the history of Zimbabwe which hitherto had not been meaningfully represented. 
In Marita, Hove presents a courageous woman whose life is dogged by endless suffering before and after independence. She is exploited by her white employer Manyepo, brutalized by Rhodesian soldiers, and also tormented by phallocentric attitudes of her African society which calls her all sorts of names when she fails to conceive. She is made to feel guilty for not being able to produce a child whilst nothing is said about her husband. The dominant beliefs that mould her society have forced her to accept without question that she is the one to blame hence she confesses to Janifa that, "I broke the water pot which my ancestors asked to bring home" (p. 13). Marita willingly accepts her societally prescribed roles as a wife and child bearer, the subservient roles in society that view men as the unquestioned head of the family. These she accepts as immutable givens. It is this kind of depiction that raises questions on Hove's craft in creating women who meaningfully question their condition. Hove depicts Marita as definitely a product of her acculturation who cannot think beyond her socialization that her husband could also be barren. She is, in a way, imprisoned in her femaleness, a victim of her gender. Such a portrayal of Marita's psyche point to the existence of a strong force that explains her behaviour, and this force is the ideological presence of a phallocentric perspective which serves to subdue women's perspectives of self. As Abbott and Wallace cited in Evans (2003: 16) argue, “...the power of men over women is collective, society's sexist assumptions advantage all men...." While we commend Hove for bringing out these destructive forces, we condemn him for abandoning these women at the mercy of the forces. Granted he gives Marita 'a voice' but he does not give her the mental wherewithal to act meaningfully to change her situation.

In fact, there appears to be a contradiction in Hove's depiction of Marita. On one hand he paints her as a courageous woman shown when she alone challenges Manyepo's slave driving techniques.

\section{But you used to tell Manyepo that work with no rest was not good for the \\ body. Now I do not know who will tell Manyepo these few things you used to tell him about us (p. 19).}

These words alone paint a picture of a brave character, an admirable woman who is a beacon of hope not just as a representative of the female's contribution to the struggle against oppression, but also as a perceptive being compared to the male folk around her. She indeed is painted as the leader, "Marita, you were once fire itself, pure fire that ate into the heart of those who thought they were made of stone" (p. 20). She had tormented the likes of Manyepo, Chisaga and even her husband Murume and one would have expected her to go on tormenting her adversaries (all males) without relenting or at least with a sustained conviction about her beliefs. This, sadly, is not to be as Hove unbelievably turns around, in the latter stages of the text, to portray an ignorant, simplistic Marita who walks into her death largely because she does not understand fully the forces pitied against her. Her death comes as a contradiction, an antithesis that point to Hove's shortcomings when it comes to meaningfully presenting the case for women's emancipation. His depiction of Marita is largely male centred, bordering on stereotyping which feminists are opposed to.

In allowing Marita to take the perilous journey into town, perilous in the sense that she is immediately vulnerable as she is unschooled in the ways of the city, Hove destroys all the hope he had built around her. He deliberately betrays her by not empowering her with the wherewithal to continue functioning effectively even in the city. Further, a close analysis of the main reasons why Marita decides to go into the city brings further proof of her naivety. She tells Jenifa that she must go to the city to search for her son so that he could come home and get married to her (Jenifa) his childhood sweetheart. Finding her son and making him marry Jenifa became her main focus, and all other serious issues of freedom and women's emancipation became secondary. The kind of reasoning all but trivializes Marita's preoccupations as a character. It works to disqualify her from an agent that can bring about meaningful change, since to her, happiness is still perceived from the traditional discourse as emanating from motherhood that must be rewarded with a daughter-in-law. While the act of going to the city appears to point to Marita's courage, it is at the same time a source of ridicule and magnifies her stupidity. The net effect of her going into the city is to reduce her to an unlettered simpleton, an object of pity deranged by ignorance. Such depiction of women (rural) by Hove far from giving them a voice in fact is an indictment of some sort that works against 'activist' feminist thinking (Kalu, 2001) whose thrust is to portray women positively, women who represent real chances of meaningful change. Marita is no such character, neither are Miriro and Tariro in Ancestors nor are Johanna and her mother in Shadows.

\section{Is Silence Golden? Quiet Women in Shadows}

Hove's androcentric portrayal of women continues in Shadows. Put briefly, Shadows traces the tragic love affair between Johanna, the heroine of the story and Marko, a young village herd boy. Unlike in Bones where the writer allows his characters to narrate their experiences without authorial intrusions, in Shadows Hove takes an 
omniscient narrative voice that explores the thoughts and feelings of his characters when facing settler-influenced constraints. The story is set in an idyllic rural area, Gotami's lands (a farming area) and focuses on the suffering of rural people as they struggle to survive in a harsh colonial and post-colonial world. For these reasons, there is a lot of intertextuality between Shadows and Bones. That the two lovers fall in love is accidental; while Marko desperately loves Johanna, she on the other hand, has surrendered her heart to someone else, 'the boy with the civet cat of a mouth'. Like Janifa in Bones who must wait for Marita's son to return from the war, Johanna is determined to wait for 'the boy with the civet cat of a mouth' to requite her love. He has promised her, "I will marry you when the time comes" (p. 75) and true to the character of an unsullied rural nymph she clings to these words. Hove portrays a Johanna who has no other ambitions in life other than to get married to the "young man whom she desired for her husband" (p. 20). The world is closed to everything else. Johanna's behaviour tallies with Kesselman, McNair and Schniedemind's (2005: 403) argument that "when a woman's sense of identity is tied to that of a man, she is dependent on this relationship for her own self worth". She thus needs this young man to authenticate her existence, and for this reason, what is foremost in her mind is marriage. In fact, an obsession with marriage permeates the whole novel.

Johanna proudly visualizes herself in her anticipated role as captured in the words below.

Soon she would be so-and-so's mother herself, she said to herself with

deep contentment. She would be so-and-so's mother too, like her own

mother (p. 75).

Even young children sing of those they would like to marry when they come of age.

They sing, all the children learning to describe the looks of the one they

want to marry. They describe the breasts of one who should suckle their

child...(p. 47).

This preoccupation with marriage seems to stem directly or indirectly from some kind of sexual ideology that shapes the female psyche in this society. Hove creates women who seem to ascribe to the St Thomas Aquinean ideology of 'anatomy is destiny' that makes a woman feel it is somehow unnatural for her to place any activity above her reproductive role. Johanna thus becomes what she is out of a socializing process that has influenced how she thinks of herself and dictates what she ought to do with her life. Her choices seem to favour the interests of a male world, hence the androcetrism of Hove's portrayal. Her own mother adds her voice to this acculturation ideology. She objects to her daughter's protracted waiting for someone who does not seem to notice her good wifely attributes, "Does he not see that you make the best wife in these farms where hard work and endurance are the diet of a good marriage?" (p. 10). This evokes memories of Ma Shingai in Dangarebgwa's Nervous Conditions who believes that women should patiently bear the burdens of womanhood. It is such attitudes that we find unproductive since they do very little to advance women's cause. Hove continues to glorify African motherhood that feminists see as oppressive if not offensive (Kalu, 2001).

Consumed by the pain of unrequited love, Janifa decides to shut herself from the world around her, and instead concentrate on her pastoral chores. Unlike Marita, or Janifa who at least speak about their suffering, to Johanna silence is golden.

She would suffer this far many years, silently, not a word coming out

of her mouth, not a tooth showing to those who wanted to make songs

out of her misery, not a crack in the side of her heart as she dwelt on

the things stored inside her (p. 11).

Her decision to suffer silently does not help much as events turn out to prove. She fails to articulate her needs and as a result does not get words of support from anyone that accentuates her feeling of loneliness. Such a depiction of the female character goes against the objectives of activist feminism that, according to Kalu (2001: 17), seeks

to sustain a system of knowledge that believes in women's visibility

as necessary for effective participation.

Johanna is largely an obscure character, living on the fringes of her society. She is not only unlettered but also disarticulated which disqualifies her from being an agent of change. Having waited in vain for the lover who has abandoned her for other girls, Johanna eventually surrenders her womanhood to young Marko. The loss of her 
virginity to Marko, instead of lifting her to another level of consciousness about herself, regrettably becomes her death knell. Her father is decidedly against the pregnancy that results from the encounter; in anger he nearly chops off Marko who runs away, but not before he makes it clear that he is going to commit suicide. Unable to cope with her loneliness Johanna too decides to take her own life.

\section{Maybe she was tired of being left alone. Maybe she feared the loneliness \\ of one left alone by so many people, those who should have clutched her \\ to their chests (p. 100).}

Her actions echo those of Janifa in Bones who, following her rape ordeal at the hands of Chisaga, decides to withdraw into herself, to embrace insanity instead of facing her adversary head on. Death or insanity become easy routes out of one's misery and such representation by Hove serves to create an idealized image of the African woman who remains steadfast in her cultural beliefs, always trying to appear virtuous. Such characterization borders on stereotyping as Hove seems to be regressing to the broken African image. By committing suicide, Johanna is safeguarding her integrity and possibly the values of her society. Her death is something her society would understand because she has defiled the lands of Gotami through engaging in premarital sex. Marko reminisces to us.

This is the woman with whom I have defiled the land of Gotami. She

always told me that the land of Gotami was holy land which must not

be defiled. But the urge of the body had made her kill the vows which

she had not made herself (p. 50).

In other words, for giving in to the 'urge of her body' without authorization, so to speak, Johanna must die. She thus stands as the bearer of her tradition and culture, the symbol of her culture's values and essence. Such type of presentation is what Stratton (1990: 21) calls the 'pot of culture' trope which

Analogizes women to a bygone culture which is usually conceptualized

as immutable, rendering the female figure static, conservative and historical.

What such representations serve to do is to mark women's continued subordination in society. It serves to perpetuate a status quo that definitely is beneficial to male interests. By deciding to make love to Marko, Johanna has chosen to be herself. Her action points to the need for women to celebrate their sexuality unfettered by male prescriptions that are largely selfish. We would have expected Johanna to 'grow' in terms of self knowledge after this encounter, but sadly, Hove shows her level of understanding as rudimentary, shaped by traditional discourse, hence largely conformist. Such tame women like Johanna, are thus, an advantage to patriarchy since failure to actively voice their problems perpetuates their subordination. Hove, thus fails to empower his women to take full control of their lives as say Adiche in Purple Hibiscus or Dangarebgwa in She Nolonger Weeps. Hove continues with this type of representation in Ancestors.

\section{Male Voices in Female Bodies - The Spirits Speak, but is Anyone Listening?}

The story of Ancestors revolves around a young man, Mucha, who is 'visited' by the spirit of his ancestors Miriro and Tariro that seek to force him to tell their story. Miriro and Tariro's spirits are restless because their human lives were characterized by endless suffering at the hands of patriarchy. Mucha must tell about their ill-treatment, their ostracism and silencing by men which saw them living painful lives. These ancestors are bitter and will not rest until their stories are heard. They thus seek somekind of retributive justice from those responsible for their pain - men. In brief, theirs is a story of pain coming from being denied opportunities to become themselves, pain that comes from being coerced into arranged marriages and pain coming from being denied opportunities to love as they pleased. Their choices and sensibilities are never taken into consideration which results in some kind of emotional torture, ultimately leading to their premature deaths.

Miriro, the elder of the two ancestors and the heroine of the story, is born deaf and dumb. Her own people see her as a bad omen, a thing not to be associated with and she is therefore, never welcome into her village of origin. She literally grows up on her own, ostracized from society with no friends to play with. When she is viewed as ripe for marriage she is forced to marry an old drunk who happened to pass through the village.

Then one day a man, drunk and worthless, passes by staggering home

through the village. "The silent one! The silent one!" the man shouts...I

will marry the silent one. The one everybody despises. Give her to me" (p. 146). 
This forced marriage is unacceptable to Miriro, it marks the extent of her betrayal, her rejection by society. With bitterness, she takes her own life only to resurface as a dream and a voice through Mucha more than a hundred years after her death. Mucha must now recount her lived experiences, be her voice so to speak, to lay bare the pain she went through as a mortal.

Tariro, unlike Miriro, is born with a voice but one that is never taken seriously. She too, like Miriro is forced into early marriage, even before she understands what marriage is all about. Her happiness is nipped in the bud because just as she looks forward to enjoying her teenage life, as she yearns for the day she will be courted by the most handsome lad in the village, she is led to marry old Musindo, an act described by Mafunga's wife as "marrying a grave" (p. 112). Like all Hove's female characters Tariro is unlettered. School to her is a waste of time.

As for school, it can wait until her own children go to waste their

time with the angry school teacher...Tariro has seen girls whose

girlhood was wasted at the school. Big girls listening to children's

stories told badly by the teacher. No man wanted to marry them (p. 105).

Such portrayal, rather than highlighting the plight of women in traditional African set ups serves to ridicule them and show them as deserving the ill-treatment they get. Top most on Tariro's mind is marriage, a marriage in which she would serve her husband dutifully in the traditional sense. What irks Tariro is the fact that in all this, she is never consulted, but she is expected to obey the dictates of patriarchy without question. Accepting this arrangement would, however, totally shatter her dream of an ideal marriage hence she decides to run away to Lusaka hoping that her rebellion would deter patriarchy from similar abuse of the girl child in the future. While her rebellion is a positive move against male domination, her death is some kind of anticlimax. Her earlier bravery is totally obliterated and it appears it was all labour lost. Hove again, betrays his heroine and makes it appear as if the struggle against male domination is all in vain. A more meaningful depiction would have at least empowered Tariro to survive her ordeal so as to give some kind of hope in the text. We see the same depiction in Marita and Janifa in Bones as well as in Johanna in Shadows. All these women characters worry about trivial issues that point to a very shallow understanding of their predicament. Their yearnings are largely male yearnings in the sense that what they aspire to become serves the interests of patriarchy. Their dreams do not in any way threaten the continued existence of male defined social structures. It is such depiction of the female psyche that makes Hove's characterization essentially androcentric.

In Ancestors, over and above the voices of Miriro and Tariro, Hove also presents Tariro's mother's voice. Tariro's mother, pained by losing her child challenges the ancestors by speaking against traditional practices that bring pain to women.

\section{If the ancestors take away my daughter, I curse them, ...No, my child}

must never return if she returns to the hands of an old man. No my

child was born like everyone else. She must come back to me, not

anywhere else...(p. 121).

Her defiance though commendable, comes a bit too late. She had quietly conspired with the male order to have Tariro 'marry a grave'. Her defiance is registered now because the marriage has not worked out and Tariro has disappeared. Her outburst is therefore not a genuine complaint against this practice of forced marriages, but more of a dirge for her daughter. In other words, had Tariro stayed and accepted the marriage, her voice would not have been heard. In any case she too had been treated like her daughter, she had been made to marry her first husband, the carver, when very young. Fortunately for her, her marriage had worked.

In her society, it is taboo to curse the ancestors hence the reward she gets for speaking against traditional practices is rejection by her husband, "From now on, I will not consider you my wife" (p. 125). She is banished from her matrimonial home together with her children for whom she now has to fend for. Without her husband, she becomes helpless, totally vulnerable and does not appear to have any working alternative in a life without Tariro's father (who apparently is Mucha's father as well). Hove does not reward her brave voice but instead seems to suggest that her rebellion is imprudent through showing her suffering thereafter. Through such a portrayal, Hove perpetuates negative perceptions of women by showing her socio-economic status declining as a result of her rebellion. Since she is uneducated, she writes a letter to her elder son Fanwell through Mucha, asking him to help by providing a home for her young children.

Things are not right for me and the children, I have told you this...Soon 
I will be sent away. Where do I go? What do I do with these children? (p. 162).

Mucha's mother is very exposed, a condition that will not be envied by any woman. Such a depiction of women is counter-productive. It can hardly inspire a defiant attitude in other women. The world of Ancestors remains male centred, with women remaining appendages to men for their survival. All Hove's women characters are uneducated, simple rural women whose chances of directing change are very limited. Infact, their simplicity is their undoing.

In addition, Hove's central female characters in Ancestors, namely Miriro and Tariro never really develop to have a meaningful physical presence in the text. They remain peripheral characters more in the dream world of Mucha's life, which appears to curtail their effectiveness as agents of change. It is sad to not that even in their privileged, supposedly powerful world of the preternatural they seem incapable of bringing up meaningful change to women's lived experiences. They remain essentially shadowy figures merely recounting their painful experiences through Mucha, but still with no real power to move the less powerful terrestrial beings into new frames of thinking as regards male-female relationships. Mucha's father cannot be said to be affected by Miriro's coming back anywhere. Not only has he had encounters with her in his own dreams, but he is also aware that she has been troubling his son to tell her story. He, however, remains intransigent, he does not listen to her message, and infact he continues to ignore his wife's feelings. "You know my pain and pretend that it is not a pain" (p. 125) she tells him. He goes on to chase her away from their matrimonial home and she, it appears, ends up the loser. We cannot say any of the men-folk are punished for ill-treating women. If anyone is punished, it is Mucha who is forced to recount his nightmarish encounters with Miriro, in a case of the sins of the fathers being visited on the sons. In the final analysis, the women are the losers in this text, as indeed is the case in the other two novels, the males go unpunished.

At the end of the text, both Tariro and Miriro do not seem to have achieved anything. The two are walking away from the land of their ancestors as if defeated. Mucha tells us, "Miriro's words are getting fainter and fainter, feeble like the words of a dying old man... The two walk from this land of ancestors in which they have lived with tears in their eyes and burdens in their hearts" (p. 195). The restlessness continues, with no sense of achievement at all in spite of the fact that their stories have been told. This is a pessimistic ending to the text which seems to suggest that efforts to accommodate women in a male world are in vain. While there is a feeling of a looming threat from the wronged women, this threat is not clearly defined, neither has it been witnessed anywhere in the text. While it appears logical that Miriro comes to haunt a man and forces him to tell her story, a more productive approach, however, would have been to have Miriro and Tariro's stories told by a woman. Such an approach would have afforded Hove an opportunity to visibilize the women and, thus increase their physical participation in seeking a new order. By choosing to give the main narrative voice to a male, Hove's depiction of women naturally becomes androcentric. Why put female voices in male bodies anywhere? Are women incapable of telling their own tales? One wonders.

In all three novels the protagonists die, having failed to sustain their struggles to a definite end. In Bones, Marita dies at the hands of an unfeeling post independence bureaucracy. Her disciple the unnamed traveler in whom we could have pinned our hopes for their continued search for justice also dies at the hands of insensitive government officials when she attempts to claim Marita's body for burial. Janifa in whose memory Marita continues to live is mentally traumatized by her brutal raping at the hands of Chisaga and is committed to a mental institution. In Shadows, Johanna commits suicide having despaired of ever fulfilling her matrimonial dreams. Her own mother remains stupefied by her painful experiences as a mother and without a single clue as to how she can end her stultifying poverty. For all intents and purposes, she is now resigned to her fate as a born sufferer. In Ancestors, as the article has already shown, Miriro takes her own life as protest against forced marriage whilst Tariro disappears and dies in a foreign land. In the text, they are no more than memories, spirits who never actively participate in the fight against male domination. Over and above this, all these women are uneducated and never really grow fully into understanding the nature of their oppression. All this serves to bring to Hove's novels an element of pessimism about women's chances of ever improving their conditions of living. Precisely, they seem doomed to continue living in the miseries and injustices crafted by patriarchy. As Zhuwarara (1996 in Ngara, 1996) observes that their struggles remain inconsequential, more of individual searches for emotional tranquility than any meaningful global change that seeks a balance of power between the sexes. And as has already been argued, their yearnings play into the hands of patriarchy in that they do not in any way threaten the dismantling of male defined social structures, but instead serve to enforce them. 


\section{Conclusion}

This article thus, has shown that while Hove in his novels seeks to give a voice to marginalized women, while he seeks to negotiate spaces for them in a predominantly patriarchal world, his presentation is largely androcentric. What he articulates about women is largely from a male point of view whose effect is to further entrench societal views of women instead of changing them. Hove just presents women as women, helpless, wronged and needing male sympathy. His women do not meaningfully take the initiative to change their positions in relation to men they live in response to the whims of men and remain largely simplistic in their interpretation of their socio-historical circumstances. Hove hesitates as a writer to create strong female characters as in the mould of Ba's Mirrielle in Scarlet Song or Dangarebgwa's Martha in She No Longer Weeps. These are women with strong convictions, who know exactly what they want to achieve and are unwavering in their determination. What Hove simply does is to invite the reader to share in and witness the pain the women go through at the hands of patriarchy, and then as if in despair, presents their fate as an immutable given. It is such a portrayal that does very little to further the cause for women, hence its androcentric nature.

\section{Primary Sources}

Hove, C. (1988). Bones. Harare: Baobab.

Hove, C. (1991). Shadows. Harare: Baobab.

Hove, C. (1996). Ancestors. Harare: College Press.

\section{References}

Eagleton, M. (ed) (1995). Feminist Literary Criticism: A reader. London: Longman.

Engellke, M. (1998). Thinking about Nativism in Chengerai Hove's Work. Research in African Literatures, 29(2), Summer, 23-42.

Evans, M. (2003). Gender and Social Theory. Buckingham: OUP.

Hellum, A., Stewart, J., Sardar Ali, S., \& Tsanga, H. (2007). Human Rights, Plural Legalities and Gender Realities. Harare: Weaver Press.

Kalu, A. (2001). Women Literature and Development in Africa. New Jersey: African World Press.

Kesselman, A., McNair, L., \& Schniedewind, N. (2005). Women Images and Realities: A Multicultural Anthology. New York: McGraw-Hill.

Mannathoko, C. Feminist Theories and the Study of Gender Issues in Southern Africa. In Menna R (ed) (1992), Gender in Southern Africa: Conceptual and Theoratical Issues. Harare: SAPES Trust.

Meyer, A. S. (1998). Voices from the Inside: The Shaping of Language Use and Literacy in Zimbabwe (Unpublished Doctoral Dissertation). Michigan State University.

Mtarangwi, M. (2000). Feminism, Anthropology and Androcentrism". Southern African Feminist Review, 4(1), 25-35.

Ngcobo, L. African Motherhood: Myth and Reality. In Peterson, K. H., \& Wasberg, P. (1988), Criticism and Ideology. Uppsala: Scandinavia Institute of African Studies.

Stratton, F. (1994). Contemporary African Literature and the Politics of Gender. London: Routledge.

Veit-Wild, F. (1992). Teachers, Preachers and Non Believers: A Social History of Zimbabwean Literature. Harare: Baobab Books.

Zhuwarara, R. Gender and Liberation: Chenjerai Hove's Bones. In Ngara, E. (ed) (1996), New Writings from Southern Africa. London: James Currey. 